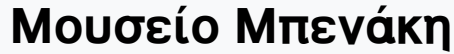

Tóp. 7 (2007)

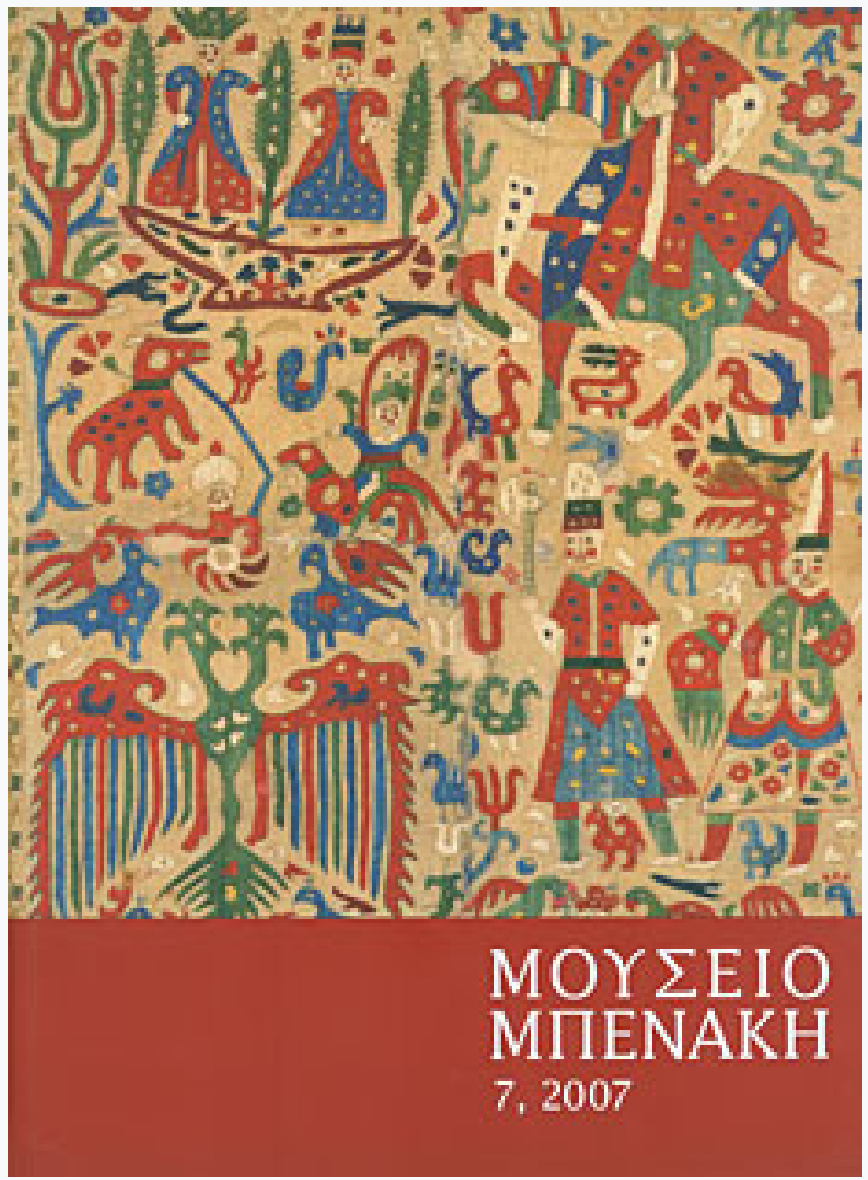

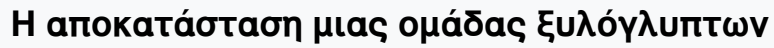

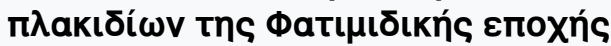

Mina Moraitou

doi: $10.12681 /$ benaki.53

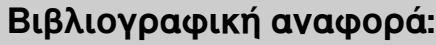

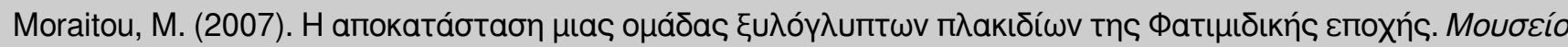

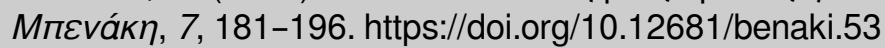




\section{The reconstruction of a wooden screen in the Fatimid style}

The Benaki Museum has of a group of woodcarvings which consists of a pair of shutters and 26 panels of various sizes. They were bought by Antonis Benakis from Egypt in 1948, almost two decades after the opening of the museum. They were acquired from Phokion Tanos, one of the well-known Cairo dealers, with whom Benakis had a close relationship for many years and from whom he frequently obtained works of Islamic and Coptic art, including some of the best lustre pottery in the collection. Unfortunately, like many of the objects in the museum that were bought on the open market, there is no information as to the specific provenance of these woodcarvings. As new acquisitions they were catalogued in 1951 as "une série de fragments de bois sculpté avec décor en champlevé (animaux et plantes, époque fatimite, Xe-XIe siècles)" and were exhibited in the museum as such. This paper examines these panels as a set in the context of the arts of the Fatimid period and attempts to recreate their original arrangement.

The Fatimids (909-1171) were a Shi' ite dynasty which claimed descent from Fatima, the daughter of the prophet Muhammad. They set themselves up in opposition to the Sunni caliphs of Abbasid Baghdad and created a splendid new capital known as al-Qahira or New Cairo situated near the old capital of al-Fustat. Their area of control spread from North Africa and Sicily to Egypt, Syria and the holy cities of Mecca and Medina. The new city was a major political, cultural and commercial centre of the Mediterranean with trade routes spreading as far as India. The eleventh century Persian traveller Nasir-i Khusraw gives a vivid picture of Cairo as centred around the grand rituals of the Caliph's court and as a city of production of lavish works of art. $^{2}$ The Fatimid era was one of the most splendid periods of Islamic art with objects displaying rich iconography combined with an ornamental vocabulary of arabesques and Kufic inscriptions. Woodcarving reached notable heights as the highly stylised decorative repertoire of ninth century Abbasid art gradually became enriched with complex vegetal designs and depictions of animals and humans figures.

Description of the objects: All the panels are carved in relief with animal and floral decoration in the Fatimid style and some with geometrical design. All have projections indicating that they were once inserted into a wooden framework. As a general observation, the panels were probably painted, a fact which might explain the rather flat carving. Additional details on the individual motifs are achieved by simple incisions and punched motifs. The group is divided into two subgroups according to the colouring of the surface. The first displays no colour or just faded traces of a red substance. Certain differences in the coloration of the wood between the pieces are probably due to variations in exposure before the panels were acquired by the museum.

The first group consists of:

- a pair of shutters (fig. 1) each decorated with three inset panels bearing animals and foliage: the top panels show a rabbit above a goat among foliage; the middle panels are almost square with a goat in a roundel and four small leaf-shaped motifs in the corners. The goats have curved shaped horns and look back. The lower panels show 


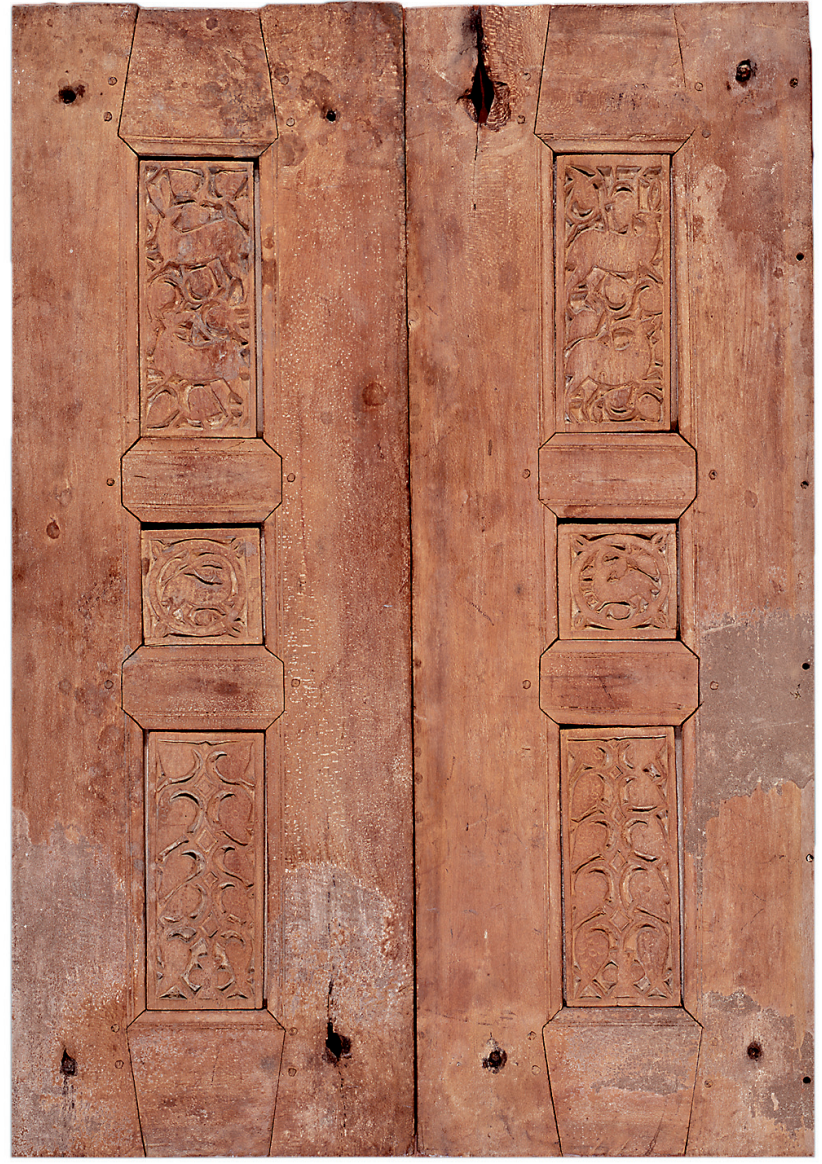

Fig. 1. Pair of shutters with inset panel decoration, carved wood, 80 x $57 \mathrm{~cm}$, Egypt, 12th century. Athens, Benaki Museum, inv. nos 9167, 9203.

an arrangement of ten leaves springing from a vase with a globular body, a flared rim and base. This vase appears essentially the same in all the panels decorated solely with foliate designs, which will be discussed below;

- two horizontal panels (fig. 2) depicting two affronted goats surrounded by leaves. The goats have long bodies sloping upwards and long horns which touch their backs. Both goats have their front legs lifted and appear to be joined together by the merging of those raised forelegs;

- four vertical panels (fig. 3) that depict a peacock standing under a foliated stem. The bird has an upright tail, an aigrette and its beak extends to form a leaf;

- two panels decorated with foliage (fig. 4) in a symmetrical composition that consists of a vase, of the type mentioned above, out of which spring stems bearing inverted leaves

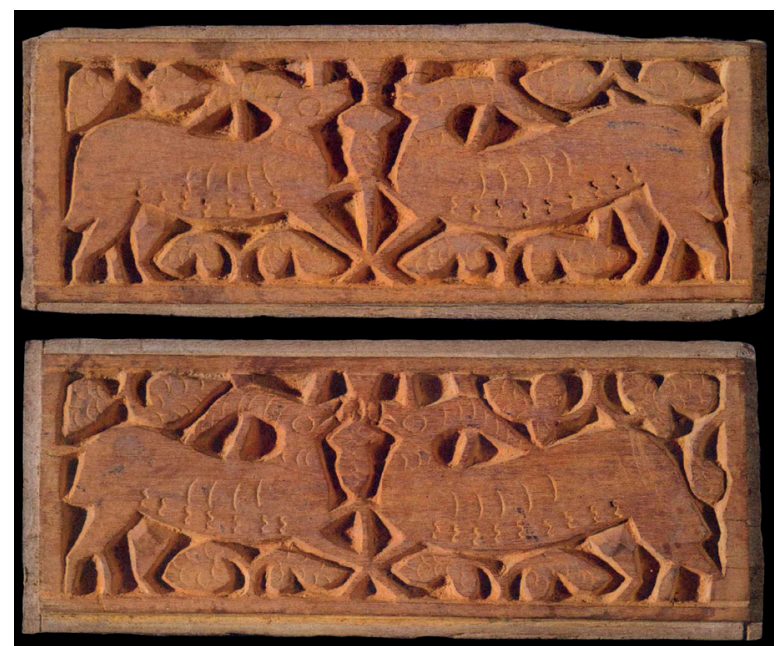

Fig. 2. Pair of panels, carved wood, 9 x $21 \mathrm{~cm}$ (each), Egypt, 12th century. Athens, Benaki Museum, inv. nos 9175, 9176.

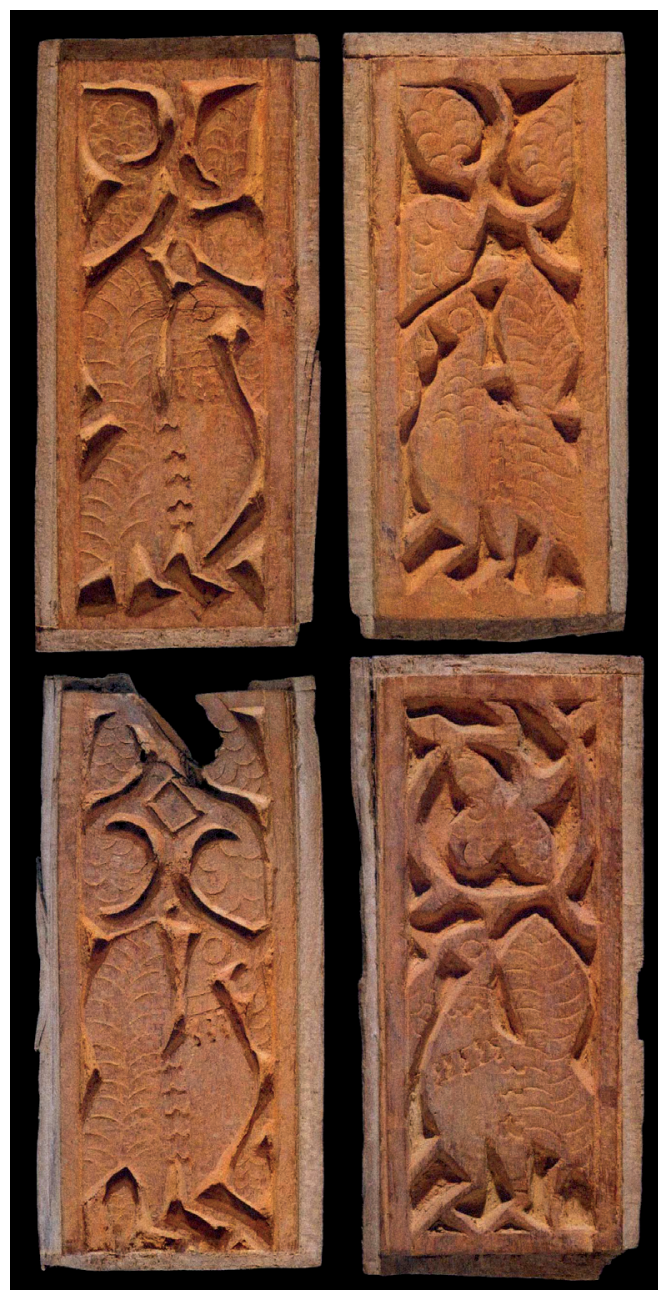

Fig. 3. Four panels, carved wood, 14 x $6.5 \mathrm{~cm}$ (each), Egypt, 12th century. Athens, Benaki Museum, inv. nos 9177, 9178, 9179, 9180. 
which form a central ogival frame enclosing a trefoil;

- four square panels (fig. 8) carved with a geometrical design. These can be divided into two pairs according to the arrangement of the design. The basic pattern consists of a six pointed star from which a series of hexagons extend laterally;

- four panels, two horizontal (fig. 6) and two vertical (fig. 7) decorated with an array of animals and birds. The horizontal panels display a procession of alternating rabbits looking back and goats looking forward, among foliage. The form of the animals is very similar to the panels described above. The vertical panels present a greater variety with the addition of peacocks, eagles with open wings and other birds looking back. These four panels connect to form an opening and have projections indicating that they were part of a larger wooden framework;

- a small rectangular panel (fig. 5) decorated with a circle which contains a radiating design, probably a cross, superimposed on a star and enclosed within the circle. This panel is similar in composition to the small panels on the shutters but substitutes the cross design for the deer (fig. 1).

The panels of the second group are fewer, only nine, and all retain traces of colour in green and light blue:

- two rectangular panels (fig. 9) which depict a single goat among foliage, whose posture is similar to the ones described above (fig. 2);

- a pair of corner panels (fig. 10) each composed of two pieces attached diagonally. The horizontal panels depict a peacock among foliage. The birds have their tails open and their wings outlined by two narrow strips. The two vertical panels present a composition of superimposed motifs: a rabbit on top of another peacock among foliage with trefoils and cone-shaped leaves. These peacocks have their tails vertical and their bodies are bulkier than those on the four panels in figure 3. The rabbits look back and their ears stand up upright;

- two panels decorated with foliage (fig. 11) in a symmetrical composition of swirling stems with inverted leaves which create an ogival shape containing two trefoils. The stems spring out of a vase similar to the one mentioned above (fig. 4);

- finally, a rectangular panel (fig. 12) with a geometrical design starting from a six-pointed star. The design is bigger and more complicated than those described above and the layout of the motifs is different (fig. 8).

Between the two groups there are many similarities

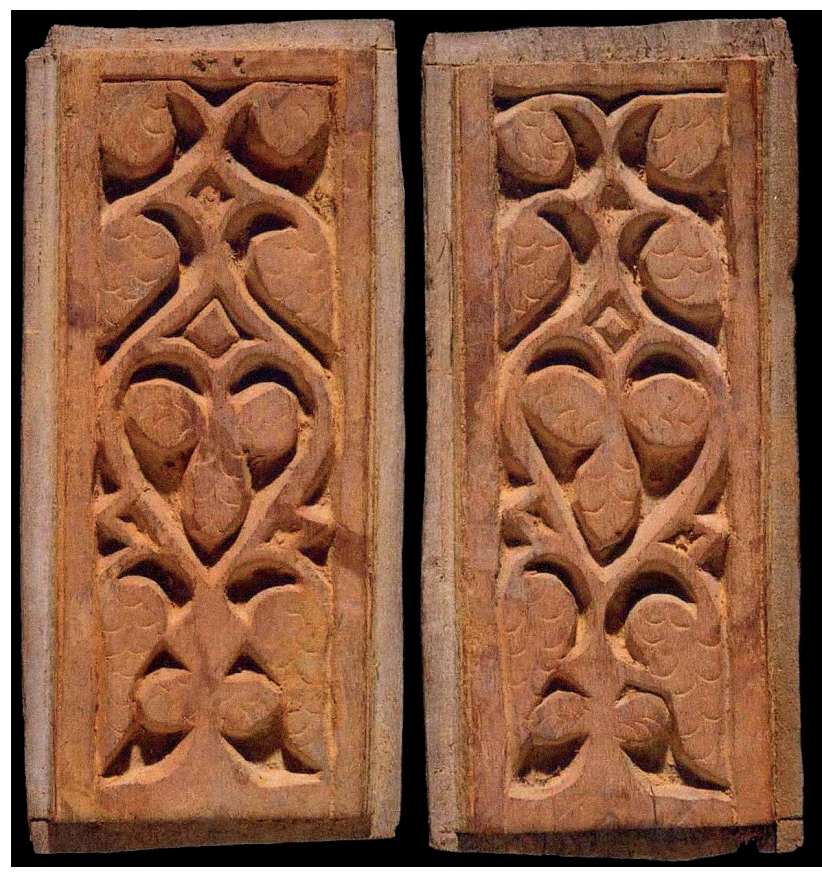

Fig. 4. Pair of panels, carved wood, 14 x $6.5 \mathrm{~cm}$ (each), Egypt, 12th century. Athens, Benaki Museum, inv. nos 9181, 9182.

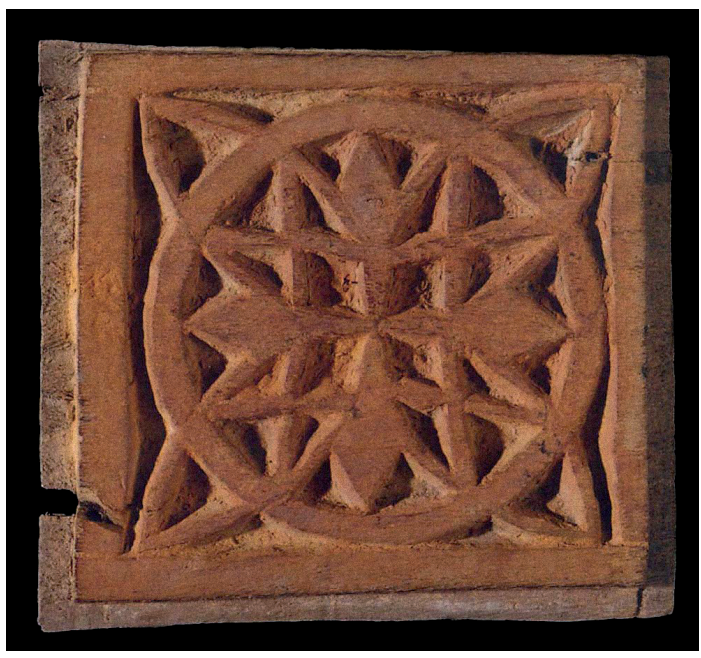

Fig. 5. Rectangular panel, carved wood, 9 x $8 \mathrm{~cm}$, Egypt, 12th century. Athens, Benaki Museum, inv. no. 9198. 

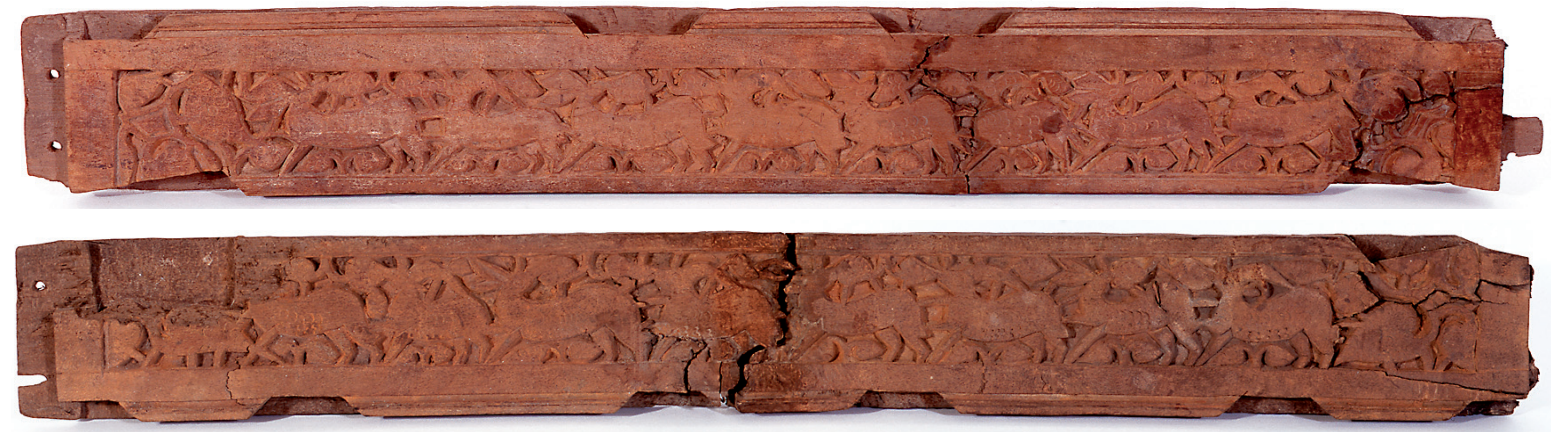

Fig. 6. Two panels, carved wood, 10 x $78 \mathrm{~cm}$ (each), Egypt, 12th century. Athens, Benaki Museum, inv. nos 10066, 10067.
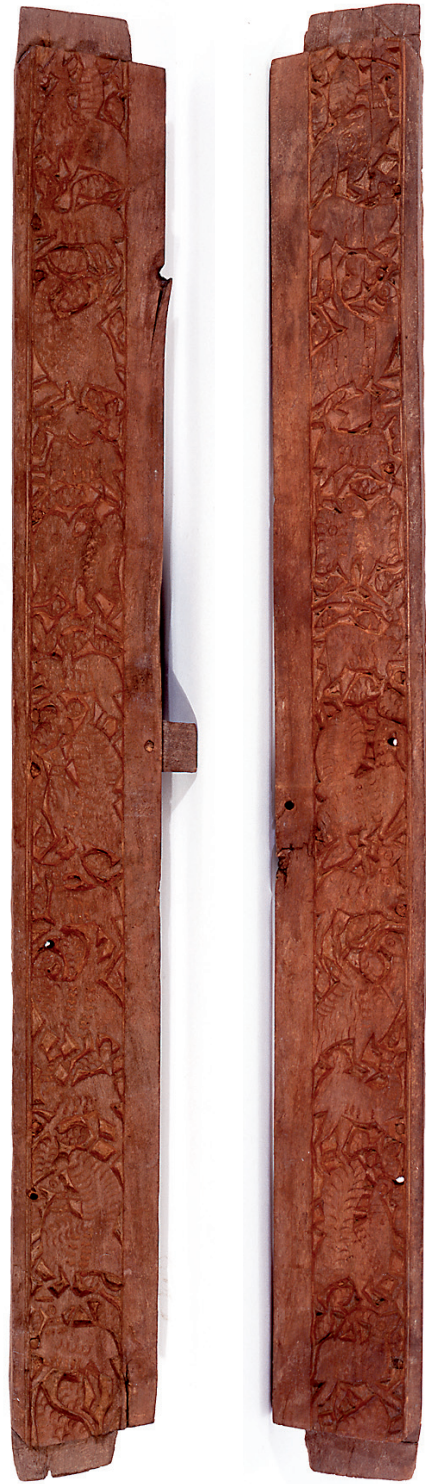

Fig. 7. Two panels, carved wood, $87.5 \times 9 \mathrm{~cm}$ (each),

Egypt, 12th century. Athens, Benaki Museum, inv. nos 10064, 10065.

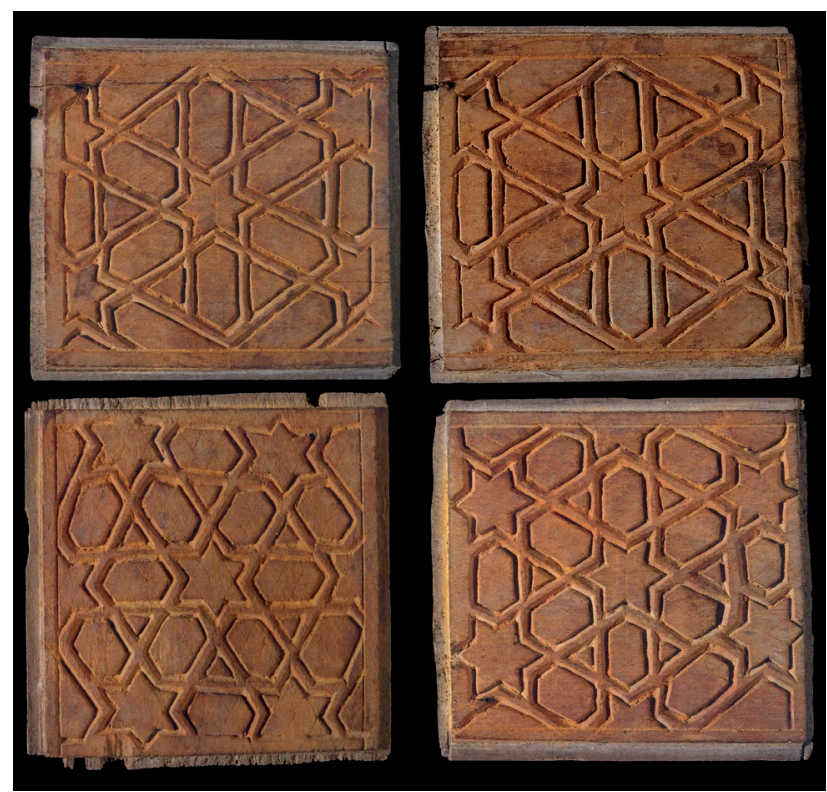

Fig. 8. Four panels, carved wood, 14 x $14 \mathrm{~cm}$ (each), Egypt, 12th century. Athens, Benaki Museum, inv. nos 9194, 9195, 9196, 9197.

suggesting that they belong to the same artistic tradition and might have originated from the same building. All the panels are stylistically similar and are made of the same wood. Wood identification analysis on some of these indicates that the wood used is ficus sycomorous, a tree native to Egypt. The quality of the carving is homogeneous, two dimensional and rather coarse with no real attempt to create depth. These carvings will be discussed in the context of the period to which they belong, i.e. in the context of Fatimid art and compared to contemporary carvings.

The fact that the iconography of the panels includes living creatures excludes the possibility that they come from 
a mosque or other Islamic religious institution. The only woodcarvings from the Fatimid period bearing figurative decoration with an identified provenance is the famous collection from the Western Fatimid Palace, the greater part of which is kept in the Museum of Islamic Art in Cairo. ${ }^{3}$ The palace was built by the caliph al-Aziz (975996) and completed by the caliph al-Mustansir (10361094) in the middle of the eleventh century. ${ }^{4}$ The site of the palace was subsequently acquired by the Mamluk sultans and the woodwork was reused for the decoration of the religious complex erected by the sultan Qalawun (1279-1290). Secular buildings from this period, unlike religious institutions which are protected by their foundation, have not survived to the same extent. As far as domestic architecture is concerned one can only recreate its decoration from a number of carved panels with rich iconography, occasionally combined with kufic inscriptions which are kept today in museum collections. ${ }^{5}$ Contemporary sources such as the Cairo Geniza records, the letters and documents which were discovered in the synagogue of Fustat, include descriptions of domestic interiors with specific references to carved woodwork, especially for doors. In his work on these documents S. D. Goitein also mentions that "Timber was indispensable in the form of logs for supports or crossbeams in ceilings on the one hand, and in that of planks in doors, screens and surfaces on the other. Carved woodwork was one of the main ornaments of buildings, both private and public". ${ }^{6}$ It is thus possible to imagine that houses were decorated with screens and doors inset with such panels.

A valuable source documenting the history of woodwork in Egypt during the Fatimid and Mamluk periods are the Coptic churches and monasteries of Fustat and the Wadi Natrun. Decorative elements in Coptic monasteries are comparable to contemporary mosques and therefore provide a useful source of comparative material. As a result, it is helpful to study some screens or iconostases from Coptic churches in connection to the Benaki material.

The area of Fustat, known as Old Cairo encompasses a number of churches dating from the period after the Arab conquest of Egypt, most of them within the Fortress of Babylon. These churches have their own history parallel to the buildings erected by the Arabs in the new city of Cairo. The churches have changed considerably over the centuries due to additions and repeated reconstructions, mostly due to damage resulting from acts of anti-Christian fanaticism.

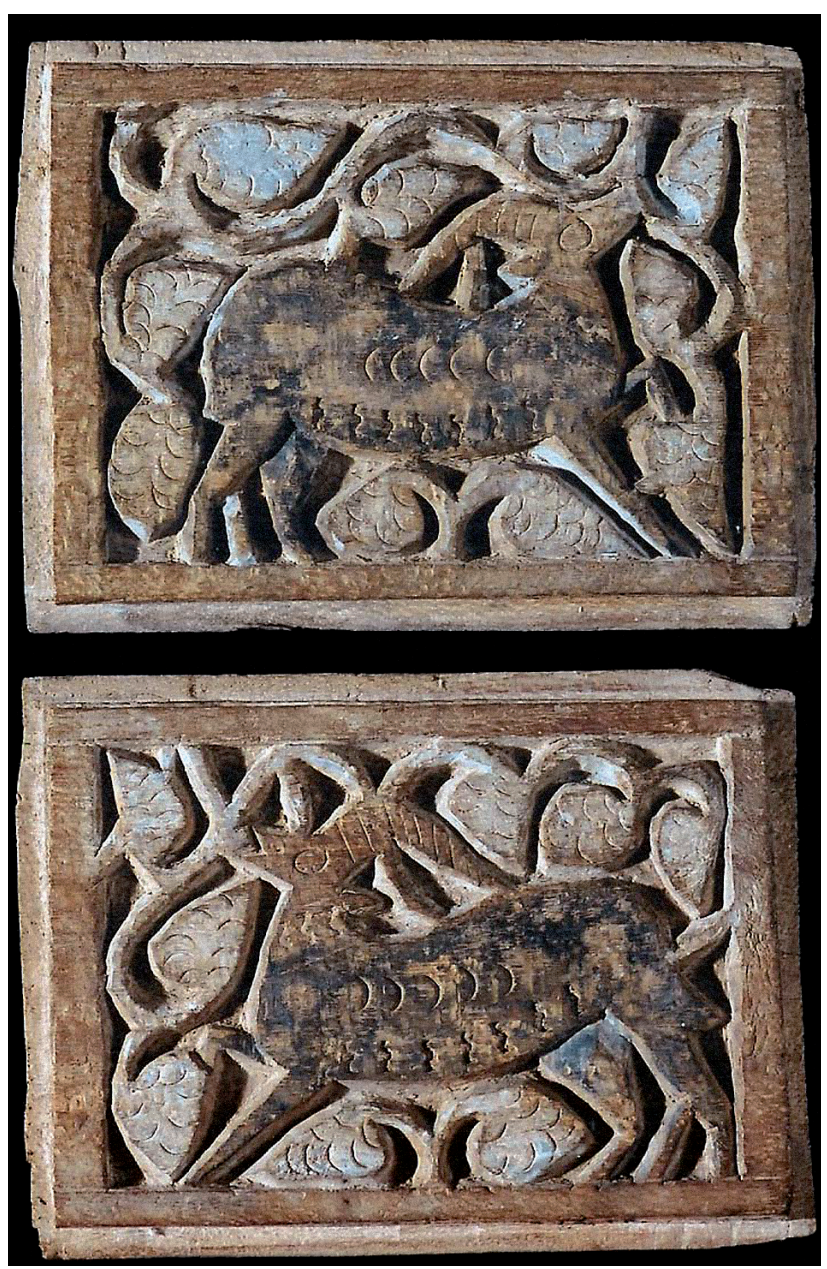

Fig. 9. Pair of panels, painted and carved wood, $10 \times 14 \mathrm{~cm}$ (each), Egypt, 12th century. Athens, Benaki Museum, inv. nos 9190, 9191.

Two churches are particularly relevant to this discussion. The first is that of St Barbara located near the church of Saints Sergius and Bacchus; both were built by Athanasius, the secretary to the governor of Egypt Abd al-Aziz ibn Marwan (685-705). The church of St Barbara was reconstructed in the eleventh century and was mentioned by the chronographer al-Maqrizi (1364-1442) as one of the most important Coptic churches. ${ }^{7}$ From this church a number of works of art from different periods survive and are now kept in the Coptic Museum. One of these is a sanctuary screen from the chapel of St George, made of sycamore and cedar wood, that consists of 45 elaborately carved panels secured on a wooden frame (fig. 13). The panels are divided into four groups according to their size 


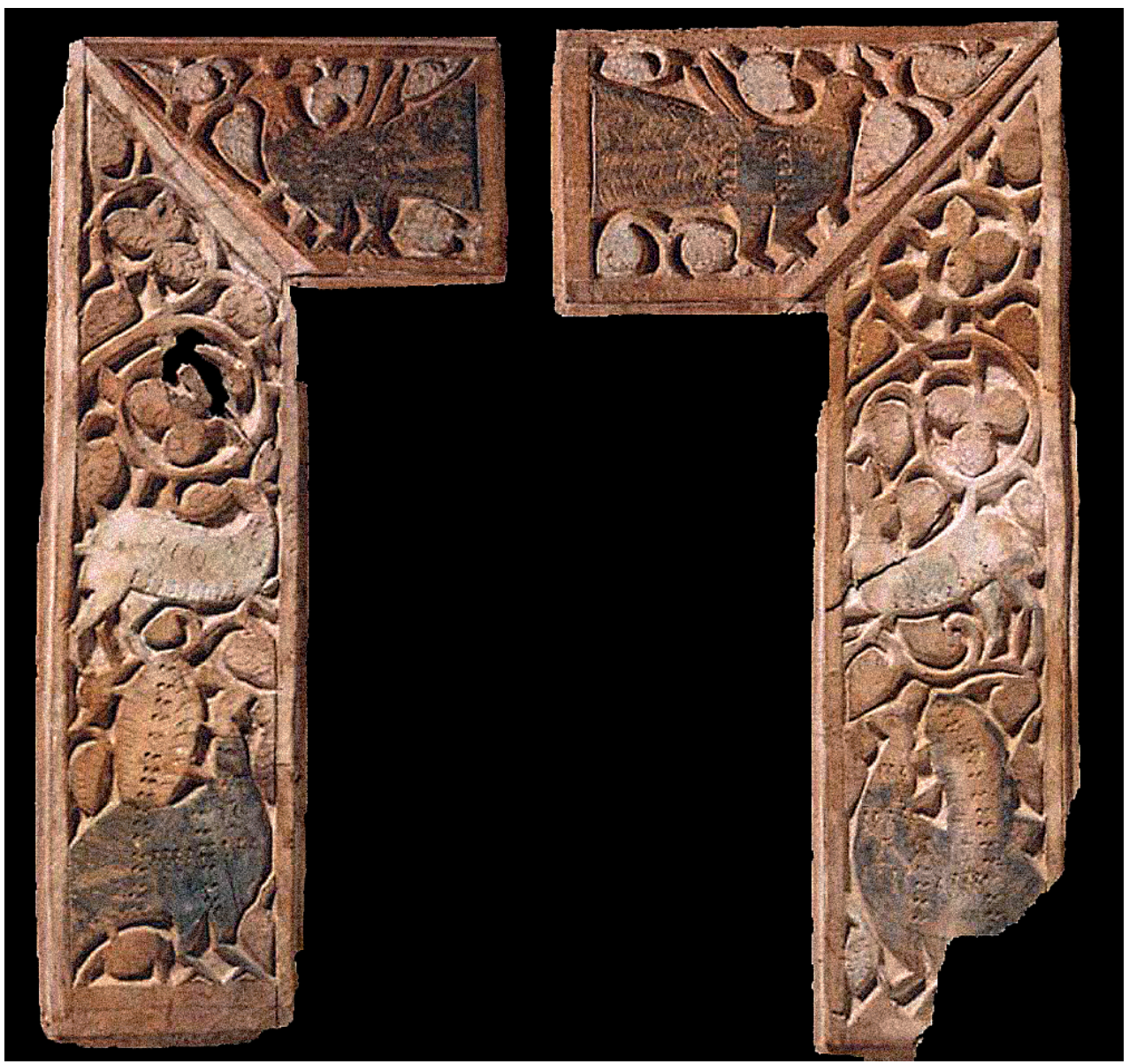

Fig. 10. Two pairs of corner panels, painted and carved wood, 36 x $16 \mathrm{~cm}$ (each), Egypt, 12th century. Athens, Benaki Museum, inv. nos 9188, 9189.

and location: eight panels decorate the central door while those on the screen are of two sizes arranged out symmetrically in eight rows. The top row displays three square panels with fine pierced decoration. The theme of decoration is secular with no typically Christian scenes, saints or crosses. There is a rich iconography of riders, hunters and musicians, real or fantastic animals either in battle or confronted among foliage as well as some panels with symmetrical floral compositions which often stem from a vase. On the whole the carvings on the iconostasis are particularly fine and elaborate, especially when compared to the Benaki panels. ${ }^{8}$

The date of the screen from St Barbara's has been a matter of discussion among scholars. The first major study of this screen was made by Edmond Pauty in his publication on the Coptic woodwork of the Fatimid period.' The author analyses the decoration of the panels and dates them to the end of the tenth century, a period when the arts were flourishing and before the caliphate of al-Hakim (996-1021) whose reign was arduous for non-Muslims and when much pillaging of churches and persecutions of Christians took place. ${ }^{10}$ In his article on the woodwork of the Fatimid period Carl Johan Lamm agrees that such work should be dated before the period of persecutions of al-Hakim or after $1020 .{ }^{11}$ In discussing the style in which the screen is decorated he concludes that despite being in a church it belongs to the tradition of the arts of Islam. In his latest book on the arts of the Fatimids, Jonathan Bloom suggests an even later date to coincide with a major renovation of the church in 1072-1075 when the relics of St Barbara were transferred from the church of al-Mu'allaqa. ${ }^{12}$ Bloom goes on to relate the screen to the 
minbar offered to the mosque at St Catherine's monastery in Sinai by the vizir al-Afdal Shahanshah (d. 1121) during the rule of the caliph al-Amir in the year 500 (1106). The organization of the panels is similar in conception to that on the screen from St Barbara's but the carved decoration is in a more conservative manner that is reminiscent of the Abbasid beveled style which was outdated by the twelfth century but appropriate for a mosque. The proportions of the panels are informative for the reconstruction of the Benaki panels in that it illustrates an example of the twelfth-century, which uses differently sized rectangular panels set in rows within a wooden frame (fig. 15). ${ }^{13}$

The second church is dedicated to St Mercurius or Abu Saifain (as he is often depicted as a saint with two swords) and is located outside the Fortress of Babylon. Major reconstruction on an older structure was undertaken during the caliphate of al-Aziz in the late tenth century and throughout the following centuries the church gained great importance. This prominence was interrupted during the second half of the twefth century, between 1168 when it was burnt during an uprising and 1174 when it was restored. ${ }^{14}$ The damage was extensive and nothing was saved except the chapel dedicated to St George on the first floor which had probably been built in the late eleventh - early twelfth century. ${ }^{15}$

From this church two screens survive, of which the larger was originally in the chapel of Saint George (fig. 14). It displays a rich composition of panels set in a wooden framework. The decoration of the panels includes depictions of standing saints while the majority of the panels display crosses, birds or animals, real or fantastic, such as sphinxes, within geometrical compositions and foliage.

The screen is made of cedar wood and consists of a central pair of doors with inset panels topped by two curved sections surmounted by a longer panel. The doors are flanked by two openings each with a pair of shutters, of which only one pair survives. Each shutter is decorated with three inset panels. Edmond Pauty dates the screen after the reign of the caliph al-Hakim (1021-1036). He compares it to the screen from St Barbara's and suggests the period towards the end of the eleventh or beginning of the twelfth century on the basis of the quality of carving, the presence of geometrical elements and the degree of abstraction in the figural decoration. ${ }^{16}$ There is another smaller screen with a similar layout, but the doors and shutters are entirely missing as are a number of inset panels. The ones that survive
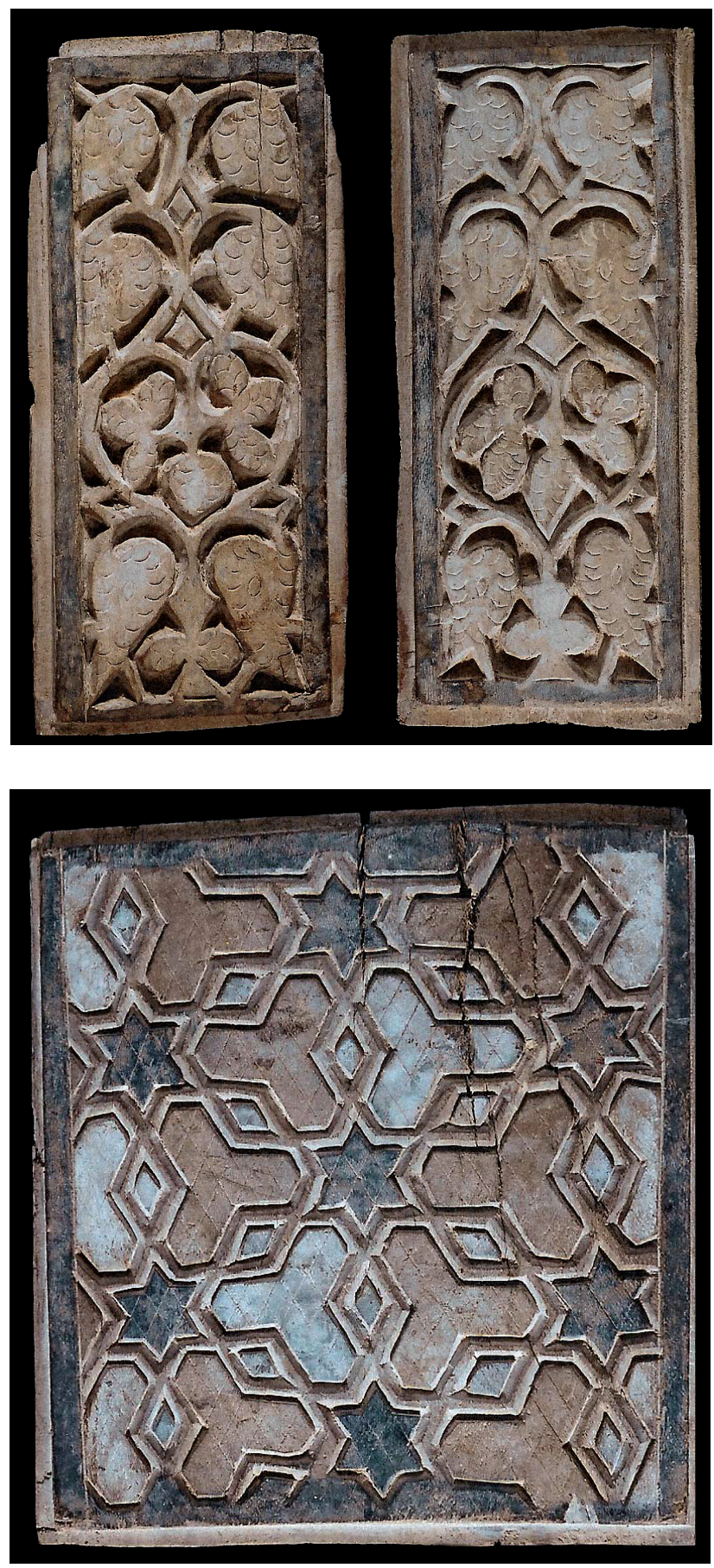

Fig. 11. Pair of panels, painted and carved wood, $19 \times 8.5 \mathrm{~cm}$ (each), Egypt, 12th century. Athens, Benaki Museum, inv. nos 9192, 9193.

Fig. 12. Rectangular panel, painted and carved wood, $20 \times 19 \mathrm{~cm}$, Egypt, 12th century. Athens, Benaki Museum, inv. no. 9185. 


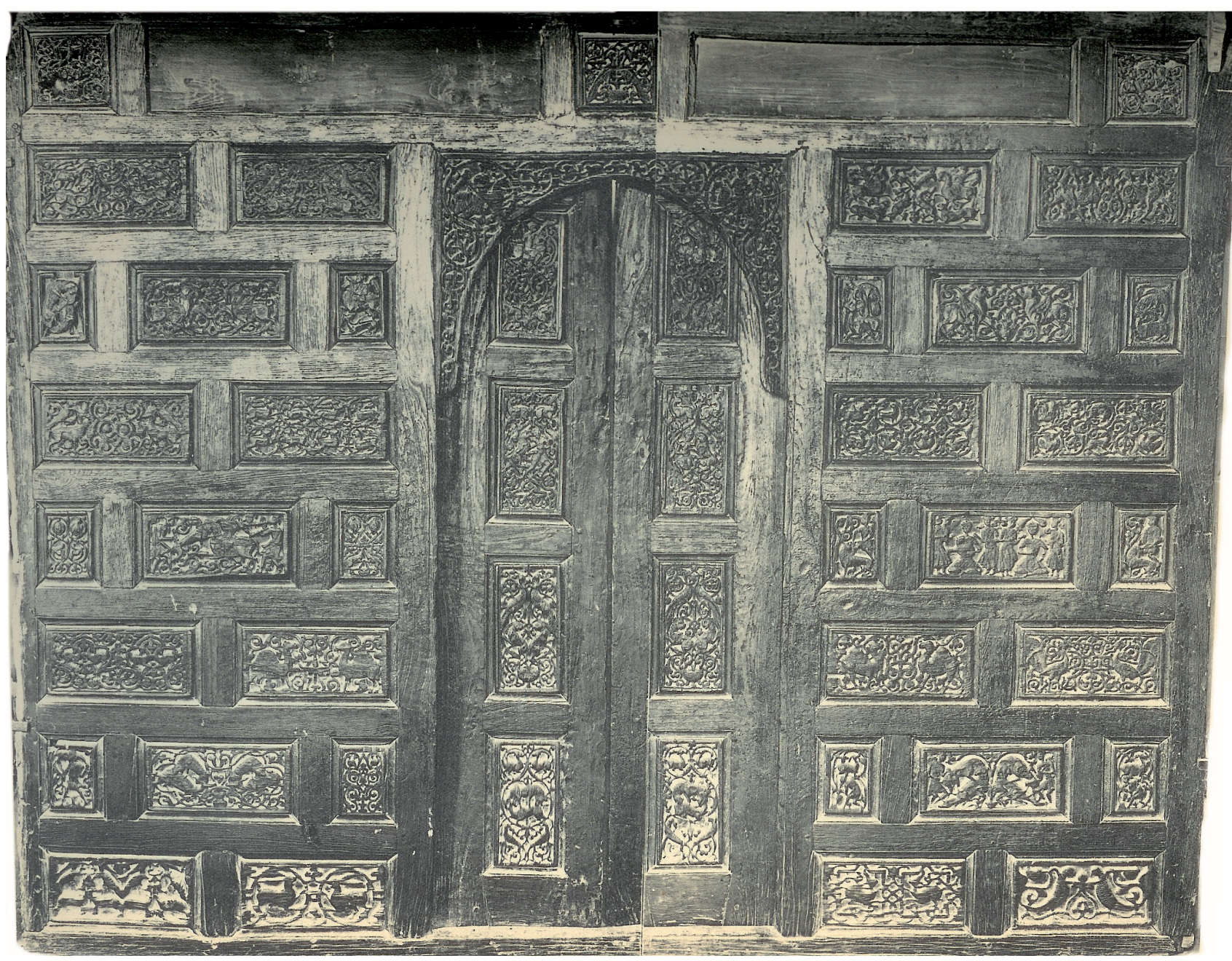

Fig. 13. Wooden screen from the church of St Barbara, Cairo (after: Ed. Pauty, Les bois sculptés d'églises coptes [époque fatimide] [Cairo 1930] fig. I).

however display similar decoration with predominantly floral motifs, crosses and standing monks carved in more detail than on the larger screen. ${ }^{17}$

After examining these screens, it is possible to assume that the Benaki panels were probably used to furnish a screen in one of the Coptic churches of Cairo, even though the only distinguishable Christian symbol is the small panel with the cross design (fig. 5). ${ }^{18}$ As a set the panels have similarities with the screens from the two churches discussed above. The fact that there is no other Christian sign links it to the screen from the church of St Barbara.
The form, size and proportions of the panels, the similarity of the pair of shutters and to some extent the quality of carving relates them more closely to the screens from Abu Saifain.

In the next section of this paper certain elements are discussed further in order to show how these panels also fit within the context of the Fatimid decorative repertoire. During this period works or art in wood in Christian and Muslim buildings in Egypt share many similarities. Mosques, churches and monasteries preserve a great deal of woodwork which is often indistinguishable, if seen out 


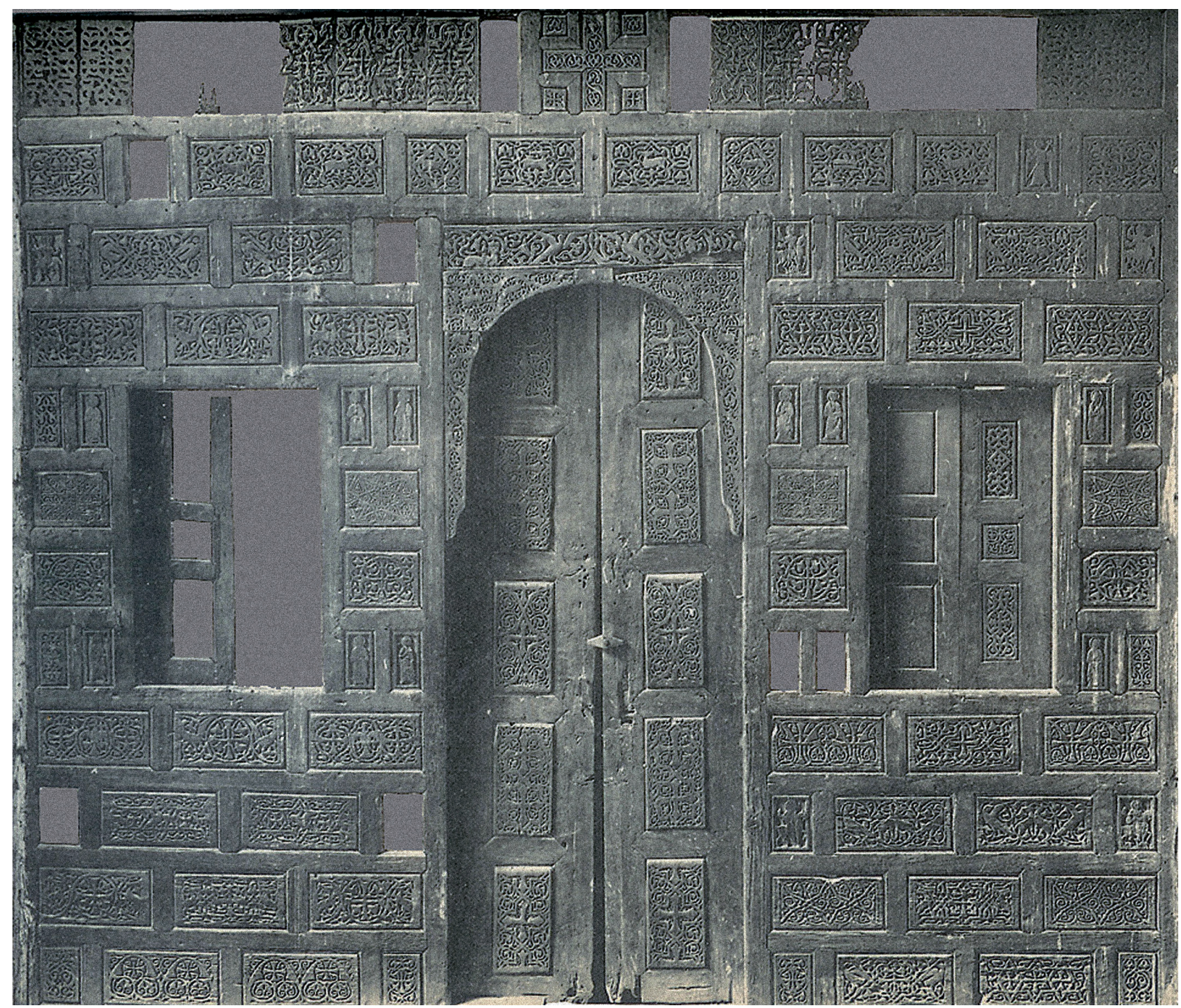

Fig. 14. Wooden screen from the church of St Mercurius, Cairo (after: Ed. Pauty, Les bois sculptés d'églises coptes lépoque fatimide] [Cairo 1930] fig. XVII).

of context or if there is not an inscription or specific Christian iconography. Given this, one may assume that the same workshops accepted commissions from both Copts and Muslims. Although the identity of the woodcarver is not the subject of this paper, it is important to note that, as regards the woodwork of the Fatimid period, Coptic and Islamic should be regarded as one artistic tradition. ${ }^{19}$

Pair of shutters: The shape, proportions and organisation of the panels is identical to that on the shutters on the screen from the church of Abu Saifain (fig. 14). Similar openings of different sizes appear flanking the central doors of screens from Coptic churches in Fustat as well as in the monasteries of the Wadi Natrun. ${ }^{20}$ The general form of a door leaf decorated with inset panels is very common since the pre-Islamic period and continues throughout the centuries. ${ }^{21}$ A monumental early Fatimid example is the well-known pair of doors from the mosque of al-Azhar presented by the caliph al-Hakim in $1010 .^{22}$

Another comparable example is not an actual door but a decorative motif on a mosque. One of the most important buildings of the Fatimid period is the mosque of al- 


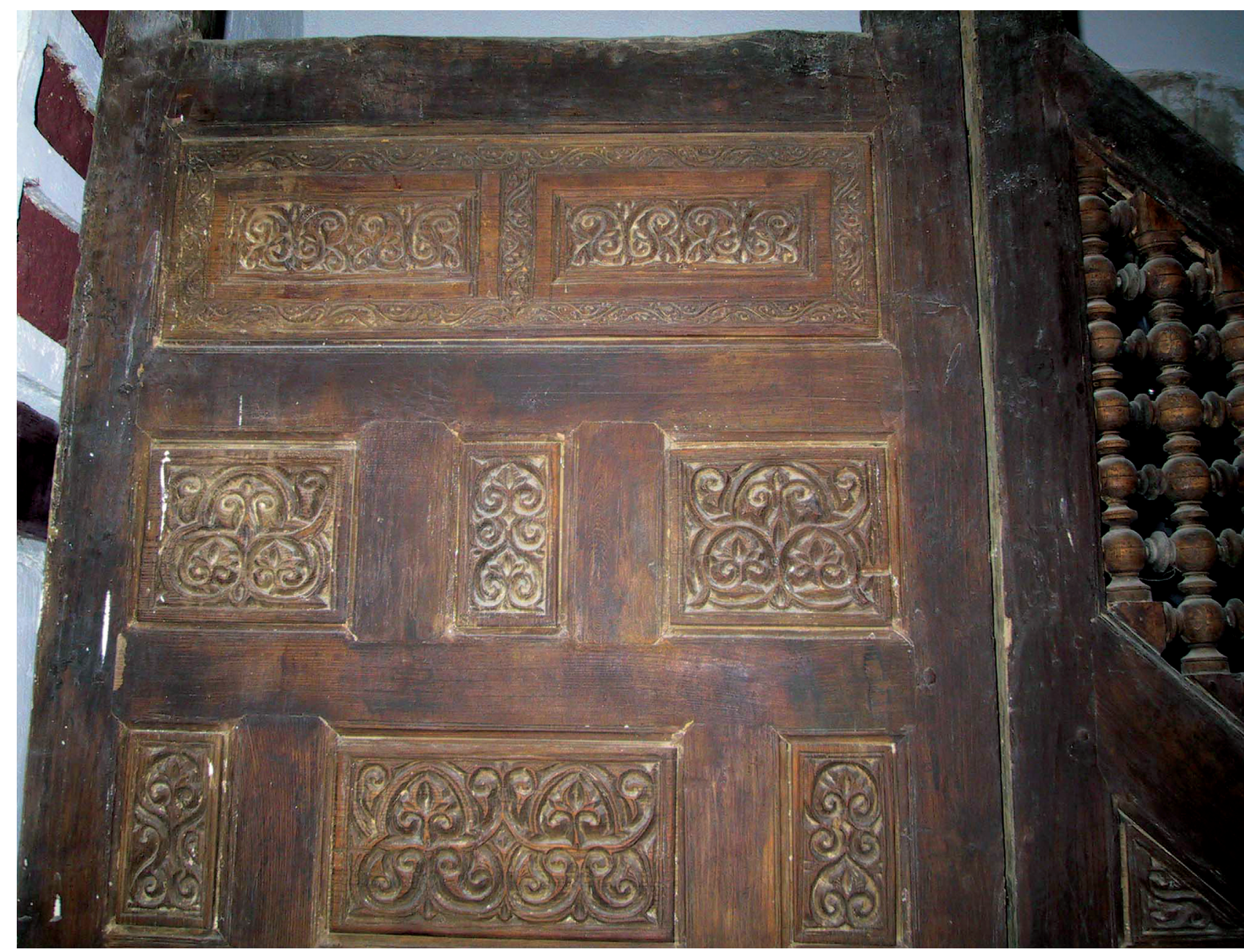

Fig. 15. Detail of the wooden minbar from the mosque at St Catherine's monastery, Sinai, dated 1106 (photo: P. Koufopoulos).

Aqmar built during the caliphate of al-Amir (1101-1130) by the vizier al-Ma'mun al-Bata' ihi in 1125 in the centre of Cairo. The most important aspect of this building is its richly decorated innovative façade. The mosque occupied a prestigious site that stood between the two royal palaces and constituted an area that was the centre of court life. The subject matter of the decoration and its symbolism has been discussed in depth by Caroline Williams and Doris Behrens-Abouseif, who give different interpretations relating to the religious or secular power of the Fatimid Isma ilis. ${ }^{23}$ Furthermore, Lucy-Anne Hunt in her discussion of the churches and mosques of Cairo suggests that the lavishly decorated façade is influenced by decorated church screens and relates it to the Christian idea of a decorated space marking the entry into a sacred place. ${ }^{24}$
An interesting element in the decoration of the façade is a design of a panelled door carved in stone, which is repeated twice and flanks the central entrance. ${ }^{25}$ The 'door' has two leaves with inset panels and is surrounded by a frame (fig. 16). The form of these doors is very similar to the pair of shutters without a frame in the Benaki collection. It is nevertheless possible to assume that the latter might have once been surrounded by the four long panels in a similar way especially since their measurements correspond exactly (fig. 17).

Corner panels: The form of two panels joined to create a corner and then combined with rectangular panels of similar sizes can be paralleled in two examples. The first is a monumental double door from the qa'a or hall of the 
Convent of St George (Dayr al-Banat) which is another Coptic site within the Fortress of Babylon in Fustat. Most of the panels survive and are decorated with intricate arabesques, typical of the eleventh century. ${ }^{26}$ What is especially interesting is that the doors are surrounded by a frame that has inset panels similar in form to the Benaki panels. The same occurs on a pair of door-leaves from a cupboard in the mosque of al-Aqmar (fig. 18). The top row has two corner panels with other rectangular panels following the corresponding vertical and horizontal alignment. Taking these patterns into consideration it is possible to assume that the Benaki panels had the same arrangement, on a much smaller scale, possibly as a cupboard or even set into a larger frame. Figure 19 shows a view of the Benaki panels in a similar arrangement to those in the monastery and the mosque. As for the panel with the geometric design, which belongs to this group, it may be assumed that it decorated the doors.

Figural decoration: The forms of the animals and birds in the decoration of the panels are very familiar and have many parallels in Fatimid iconography. The amount of comparable material in different media is extensive and therefore the relevant examples mentioned in this paper are mainly restricted to carved wood and especially the carvings from the Western Palace. ${ }^{27}$ For example, the figure of the goat, with the long curved horns and the raised front leg, whether alone (fig. 9) or as one of a pair (fig. 2) can be compared to that on a section of the palace friezes in the Museum of Islamic Art in Cairo (fig. 20). This animal in a similar form also occurs repeatedly in the decoration of the panels of the Abu Saifain screen where it is placed within a geometrical star-shaped outline (fig. 21). ${ }^{28}$

Rabbits are a recurrent theme on works of art of the Fatimid period in all media and, as a decorative motif, it has its roots in the late antique prototype that penetrated Islamic art and reached the Fatimid period in a vigorous and lively style. They are a frequent motif in Christian and Islamic iconography. The rabbit with its head turned back, as it appears on the panels, is included in the decoration on the palace beams ${ }^{29}$ and also occurs in a number of small panels in museum collections. ${ }^{30}$ In a Coptic context, a comparable image, with their heads turned and their ears raised vertically, is on the arch above the central door of the church of Abu Saifain.

The motif of a peacock is also regularly included in the woodwork of the Western Fatimid palace and particularly

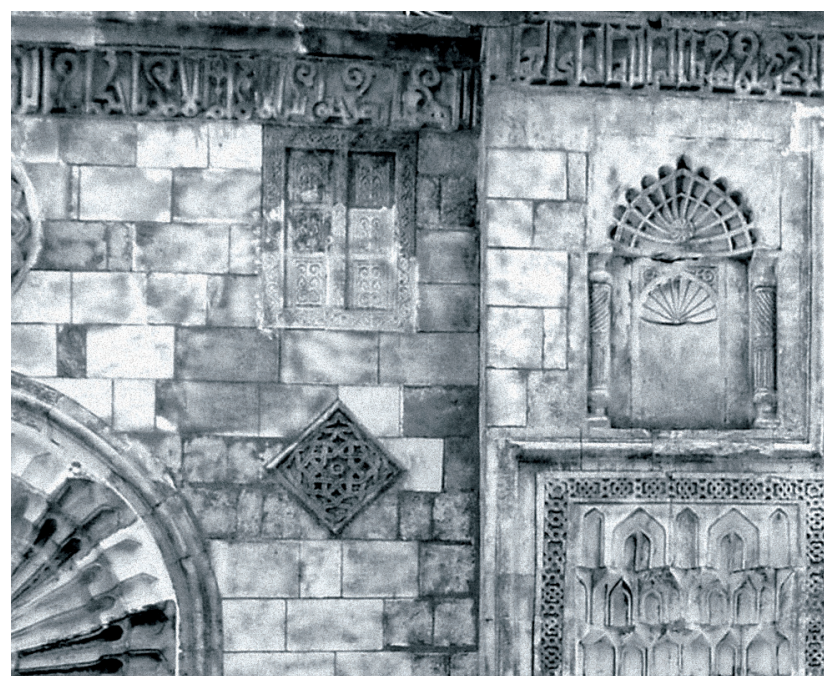

Fig. 16. Detail of the façade of the al-Aqmar mosque, Cairo, 1125 (after: www.flickr.com/photos/manna4u/ 2440862023).

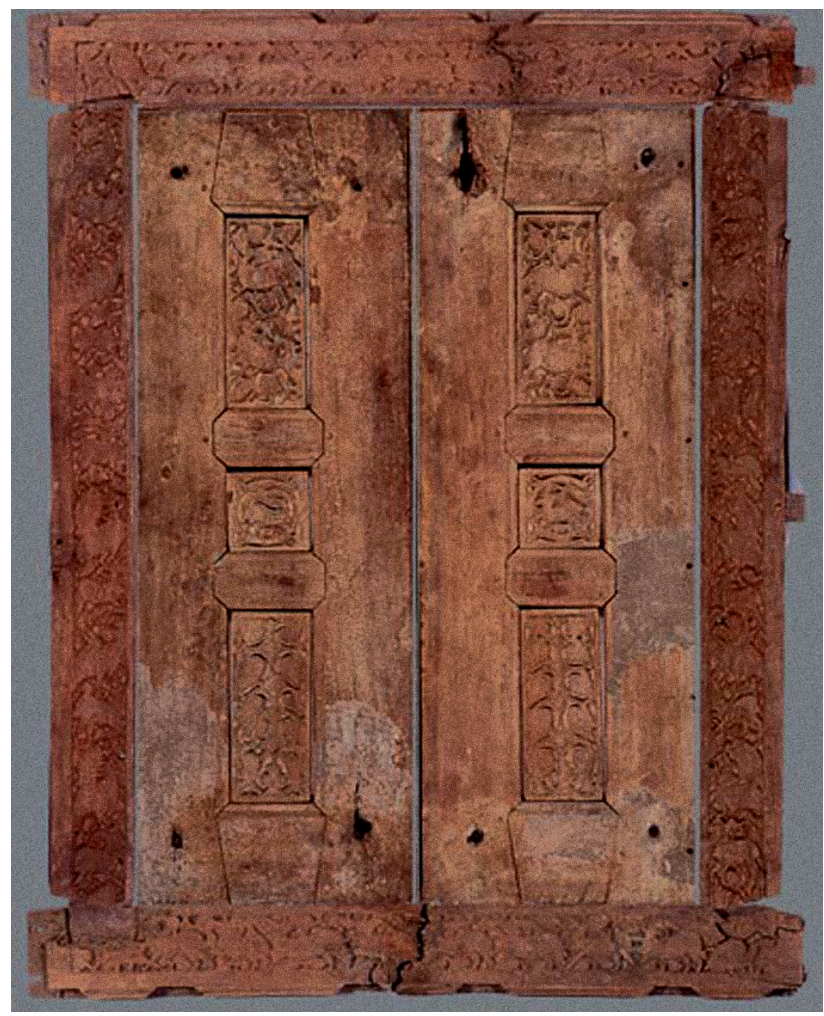

Fig. 17. Reconstruction of the panels. Athens, Benaki Museum, inv. nos 9167, 9203, 10064, 10065, 10066, 10067. 

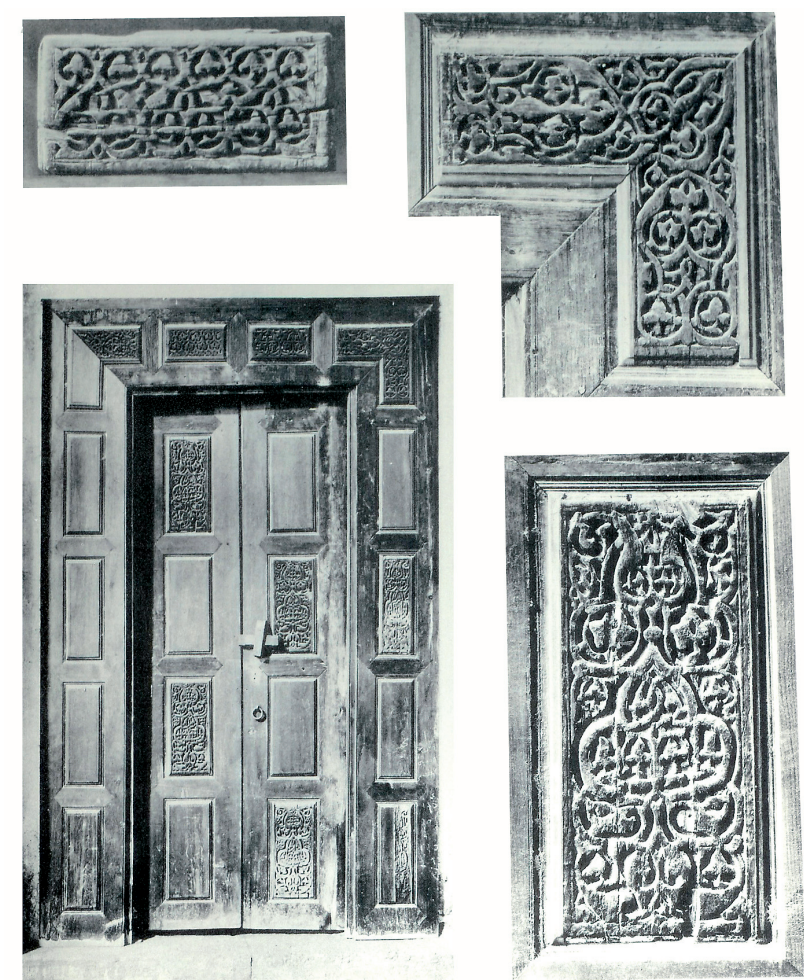

Fig. 18. Cupboard from the mosque of al-Aqmar, Cairo, 12th century (after: K. A. C. Creswell, The Muslim Architecture of Egypt [Oxford 1959] fig. 84).

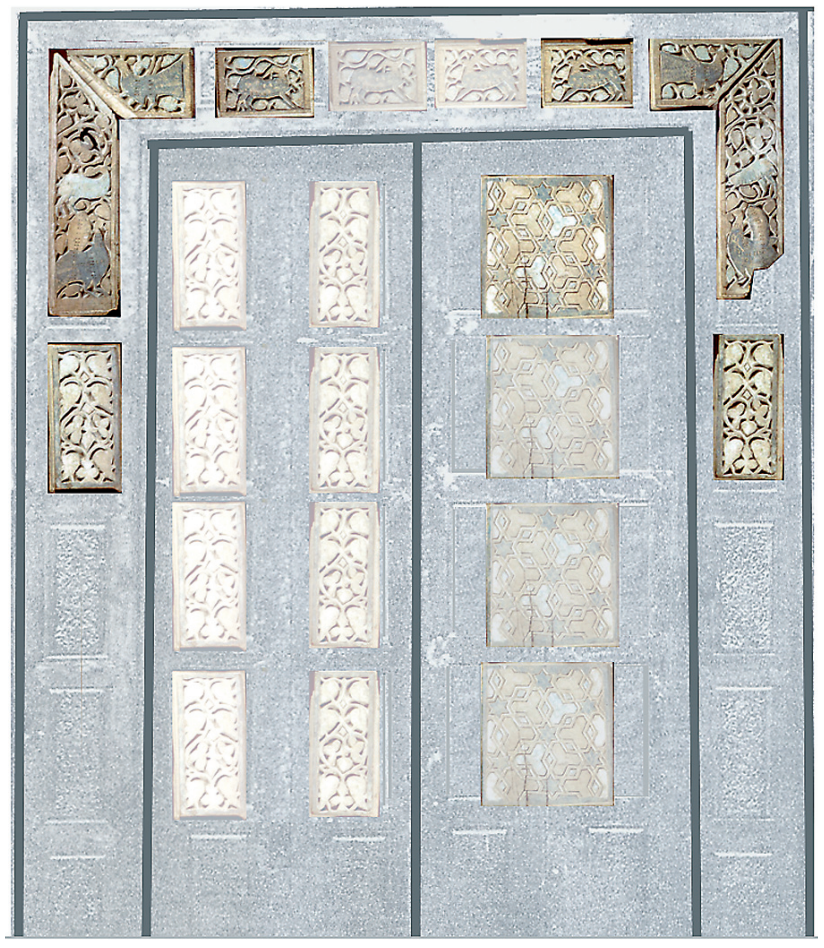

Fig. 19. Reconstruction of the panels inv. nos 9185, 9188, 9189, 9190, 9191, 9192, 9193.
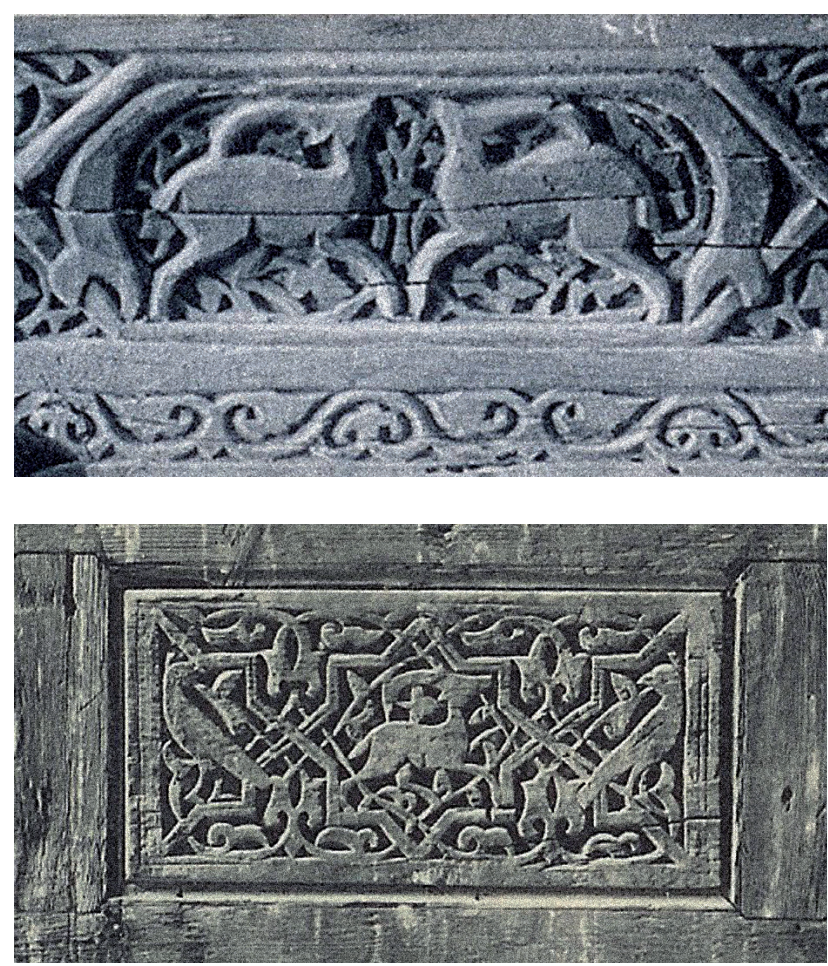

Fig. 20. Detail from the beams of the Fatimid royal palace depicting two affronted goats, Cairo, 11th century (after: Ed. Pauty, Catalogue général du Musée Arabe du Caire: les bois sculptés jusqu'à l'époque ayyoubide [Cairo 1931] pl. XLIX).

Fig. 21. Decorative panel from the screen of the church of $S t$ Mercurius, Cairo (after: Ed. Pauty, Les bois sculptés d'églises coptes [époque fatimide] [Cairo 1930] fig. XXX).

in the polylobed medallions between the 'banquet scenes' on the beams. The form of this bird is also reminiscent of a marble panel with two affronted peacocks on a background of stylized floral motifs (fig. 22). The marble panel is another case of Fatimid decoration found in a Mamluk building, this time in the mosque of the sultan al-Barquq (1382-1389 and 1390-1399), where it was reused with the figural decorated side face down. ${ }^{31}$

Floral motifs and vase with flowers: The motif of the stems that spring symmetrically out of a vase is an image that occurs in both a Christian and an Islamic context. It is a familiar Christian symbol for the Eucharist, the New Life and Paradise and is used as decoration in the Islamic era, from as early as the Umayyad period (661-750), as, 

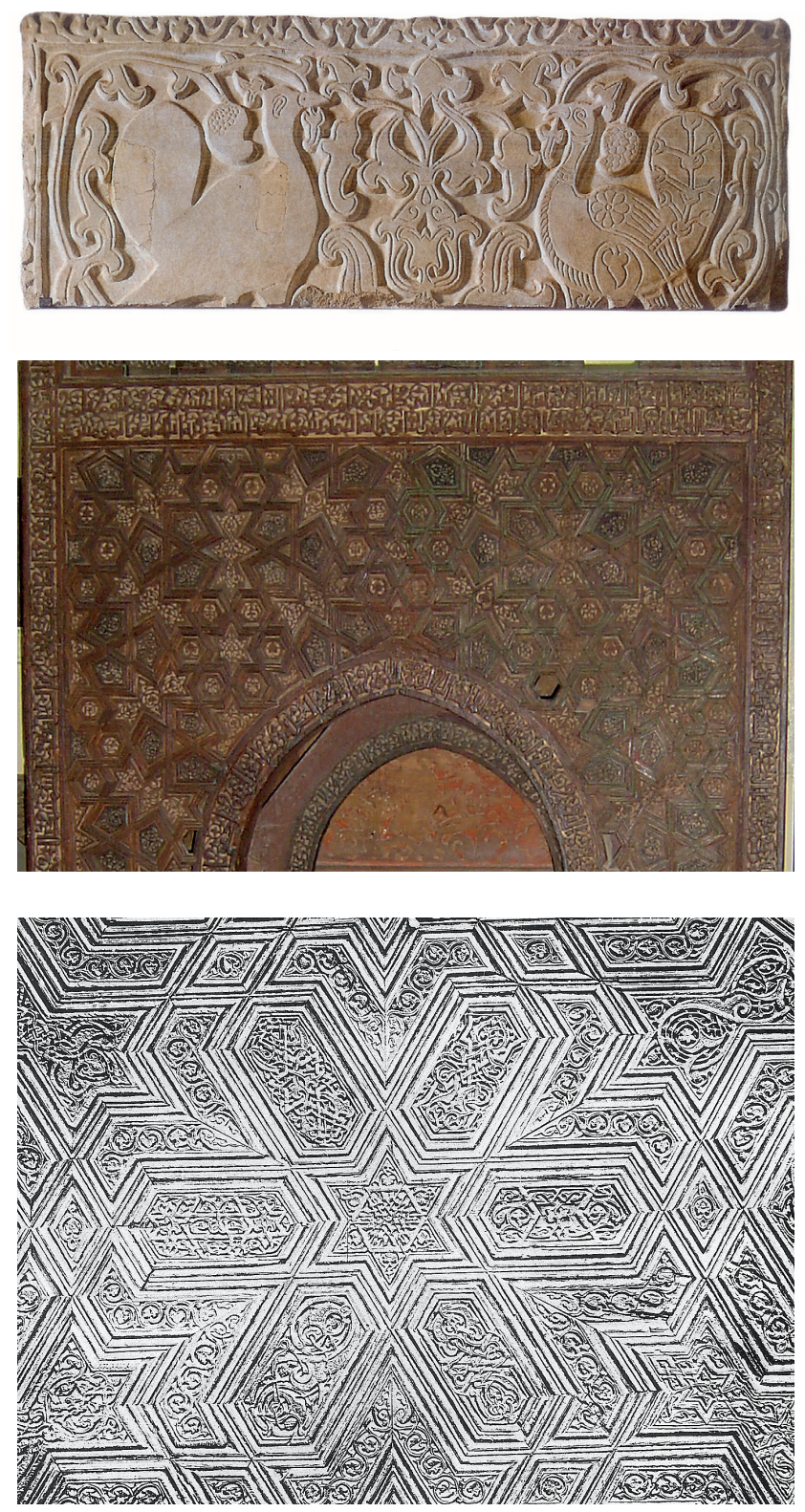

Fig. 22. Marble panel from the Fatimid royal palace, 11th century (after: M. Barrucand [ed.], Trésors fatimides du Caire [exhibition catalogue, Institut du monde arabe, Paris 1998] fig. 12).

Fig. 23. Detail of the decoration of the minbar of the Amri mosque, Qus, dated 1155 (after: Ed. Pauty, Le minbar de Qoūs, Mélanges Maspero III [Mémoires publiés par les membres de l'IFAO] 68 [Cairo 1940] 41-48 fig. II).

Fig. 24. Detail from the mihrab of Sayyida Ruqayya, Cairo, mid-12th century. for example, on the woodwork of the al-Aqsa mosque in Jerusalem ${ }^{33}$ or on the façade of the palace of Mshatta. ${ }^{34}$ In the twelfth century it appears on the carved decoration of the Fatimid wooden doors of the Fakahani mosque datable to the period of the caliph al-Zahir (1149-1154) 35 and on the façade of the al-Aqmar mosque, ${ }^{36}$ as well as repeatedly on the screen from St Barbara's. ${ }^{37}$

Geometric ornament: A rather unusual element in the decoration of this group of woodwork is the addition of the square panels with geometric compositions. Geometric designs in the twelfth century are mostly used as outlines combined with figural or vegetal motifs and do not typically constitute the main design. Moreover, since these panels are carved in relief and not made in marquetry, they are reminiscent of panels from later periods and especially the Mamluk period. ${ }^{38}$ However, their general appearance, that is the material, the quality of the carving and the design, suggest that they belong to the same group as the rest of the panels.

The design of the six-pointed star combined with the elongated hexagons is known during the late Fatimid period but only as an outline to more elaborate compositions. For example, it appears on the minbar of the Amri mosque at Qus which was commissioned in $\mathrm{AH} 550$ (AD 1155-1156) by the emir al-Malik al-Salih Tala'i in the reign of the caliph al-Faiz (1154-1160). Details of the decoration of the minbar reveal a central arrangement of six-pointed-star-shaped panels combined with elongated hexagons, all richly decorated with arabesque designs (fig. 23). Six-pointed stars are also included on the backrest of the minbar as well as in the compositions of isolated panels. Another contemporary example is the portable mihrab commissioned by al-Alam, a widow of the caliph al-Amir for the sanctuary of Sayyida Ruqayya and datable to $1154-1160 .{ }^{39}$ The richly decorated façade of the mihrab is filled with similar designs which if separated from the intricate decoration are comparable to those on the panels in figure 8 (fig. 24). Thus it is possible to suppose that the geometrical design on the Benaki panels is a simplified version of these examples and follow the relatively simple artistic way in which these panels are carved. A final comparison derives from the architectural decoration of the façade of the mosque of al-Aqmar and specifically, the opening that displays an arch which incorporates a geometrical composition under a hanging lamp which is 


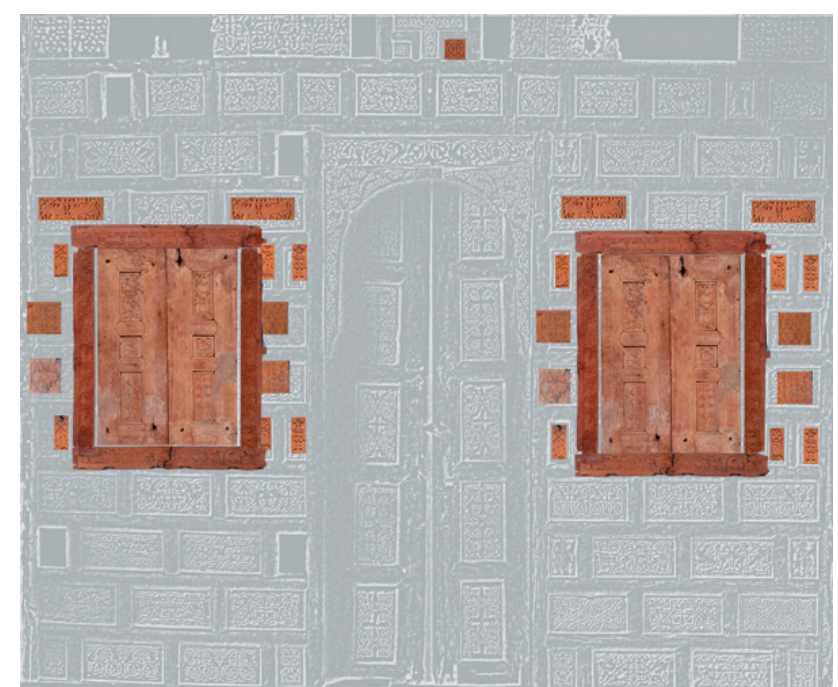

Fig. 25. Reconstruction of the Benaki panels on a church screen of the Fatimid period.

\section{Notes}

1. Chronique des fouilles et découvertes archéologiques en Grèce en 1951, Bulletin de Correspondance Hellénique 76 (1952) 206.

2. He mentions over 20,000 shops, owned by the Caliph, operating in the city. W. M. Thackton (ed.) Nasir-i Khusraw's Book of Travels (California 2001) 56-76.

3. See Ed. Pauty, Catalogue général du Musée Arabe du Caire: les bois sculptés jusqu'à l'époque ayyoubide (Cairo 1931) 49-50 pls XLVI-XLVII.

4. For the latest publication on the palace and further references, see J. Bloom, Arts of the City Victorious, Islamic Art and Architecture in Fatimid North Africa and Egypt (New Haven-London 2007) 65-69.

5. Standard Arabic inscriptions, such as "al-mulk lillah" (the kingdom is for God), or pseudo inscriptions emulating such phrases and combined with animal decoration indicate that they belong to buildings of the Muslim community, cf. Das Staunen der Welt, Das Morgenland und Friedrich II (Berlin 1995) 67 no. 70 and unpublished objects in the Benaki Museum, inv. nos 9811, 9812, 9803. See also M. Barrucand (ed.), Trésors fatimides du Caire (exhibition catalogue, Institut du monde arabe, Paris 1998) nos 10-11.

6. S. D. Goitein, A Mediterranean Society, 4: Daily Life (Berkeley 1983) 103. very similar to that on the Benaki panels. ${ }^{40}$

To conclude, the two sets of panels discussed in this paper should be treated as the wooden carved decoration from a single site. Figure 25 shows a tentative reconstruction which places the panels on a screen of the Fatimid period, similar to those discussed above. I suggest that these panels were once set on a sanctuary screen or a door in a church, dating to the middle of the twelfth century. However, I do not overlook the possibility that they were part of the interior decoration of some secular building such as a mansion. In either case the decorative repertoire belongs to the artistic tradition of the Fatimids.

Mina Moraitou

Curator of the Islamic Collection

mina@benaki.gr
7. G. Gabra - M. Eaton-Krauss, The Treasures of Coptic Art in the Coptic Museum and Churches of Old Cairo (Cairo 2007) 240 .

8. Another set of four panels, which were acquired by Antonis Benakis from the same source in the same period, is more closely related to the carvings on the screen. The set displays finer carving with more delicate details and was probably gilded. See W. Seipel (ed.), Schätze der Kalifen, Islamische Kunst zur Fatimidenzeit (Vienna 1998) 16-19.

9. Ed. Pauty, Les bois sculptés d'églises coptes (époque fatimide) (Cairo 1930).

10. Ibid. 24-25.

11. C. J. Lamm, Fatimid woodwork, its style and chronology, Bulletin de l'Institut d'Égypte 18 (Cairo 1936) 59-91.

12. Bloom (n. 4) 162-63.

13. I am grateful to Professor Petros Koufopoulos for providing me with images of the minbar.

14. Gabra - Eaton-Krauss (n. 7) 242-47; and L. A. Hunt, Churches of Old Cairo and mosques of al-Qahira, Byzantium, Eastern Christendom and Islam 1 (London 1998) 325-26.

15. Pauty (n. 9) 30; and Gabra - Eaton-Krauss (n. 7) 244.

16. Pauty (n. 9) 33-34. 


\section{Pauty (n. 9) figs XXXIV-XXXIX.}

18. Although it could also have been part of the decoration of a house belonging to an affluent Christian.

19. For further discussion on this topic, see M. Jenkins, An Eleventh-Century Woodcarving from a Cairo Nunnery, in: R. Ettinghausen (ed.), Islamic Art in the Metropolitan Museum of Art (New York 1972) 236-38; and Hunt (n. 14) 328-29.

20. Gabra - Eaton-Krauss (n. 7) 225, 233, 244.

21. Compare with the early 6th-century door from the church of St Barbara, ibid. 216-17.

22. J. David-Weil, Catalogue général du Musée Arabe du Caire: les bois à épigraphes jusqu'à l'époque mamlouke (Cairo 1931) 16 fig. XI; Pauty (n. 3) 30-31 pl. XXIII; and for the latest publication Bloom (n. 4) 63-64 pl. 37.

23. For these theories, see C. Williams, The Cult of 'Alid Saints in the Fatimid Monuments of Cairo, Part I: The Mosque of al-Aqmar, Muqarnas 1 (1983) 37-52; and D. BehrensAbouseif, The Façade of the Aqmar Mosque in the Context of Fatimid Ceremonial, Muqarnas 9 (1992) 29-38.

24. Hunt (n. 14) 329-31.

25. K. A. C. Creswell, The Muslim Architecture of Egypt (Oxford 1959) fig. 83a.

26. Jenkins (n. 19) 231-40.

27. Comparative material in ivory is also relevant, see Barrucand (n. 5); and for more examples in painting as well as in other media, see E. Grube - J. Jones, The Painted Ceilings of the Capella Palatina (New York 2005).

28. Pauty (n. 9) pls 19, 29-30. For more comparative material see E. Anglade, Catalogue des boiseries de la section islamique (du Louvre) (Paris 1988) 65, 68.

29. Pauty (n. 3) pl. L.

30. Anglade (n. 28) 69-70; Pauty (n. 3) pls XXXV-XXXVI; Das Staunen der Welt (n. 5) no. 65 in wood and nos 67-68 in ivory of the same period.

31. Bloom (n. 12) 68; and Barrucand (n. 5) 93.

32. See Bloom (n. 12) pls 62, 77; and Grube - Jones (n. 27) 244, 248-49.

33. R. Hillenbrand, Umayyad Woodwork, in: J. Jones (ed.), Bayt al-Maqdis, Jerusalem and Early Islam (Oxford 1999) 271-310.

34. V. Enderlein - M. Meinicke, Mschatta-Fassade, Jahrbuch der Berliner Museen (1992) 155 abb. 20.

35. Creswell (n. 25) pl. 92d,e; and Bloom (n. 12) 153.

36. Creswell (n. 25) pl. 83a.

37. For examples see Pauty (n. 9) pls V, IX, XII.

38. Anglade (n. 28) cat. nos 65-68.

39. David-Weil (n. 22) 11-14 pls XVI-XVII.

40. Creswell (n. 25) pl. 83a.

\section{MINA MSPAÏTOY}

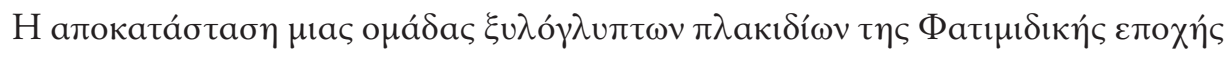

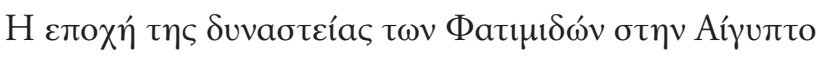

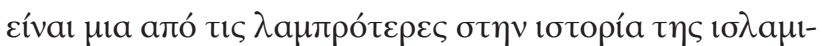
кฑ́

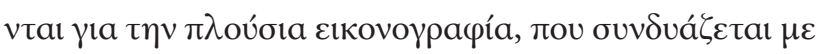

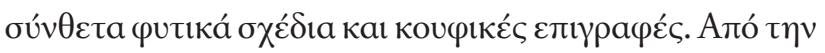

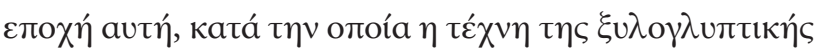

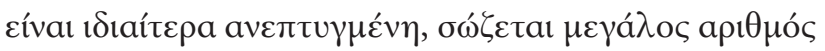

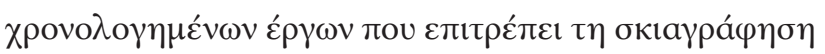

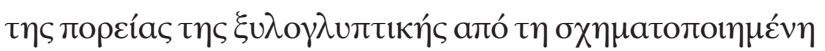

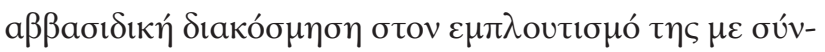

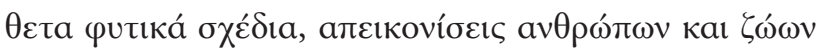

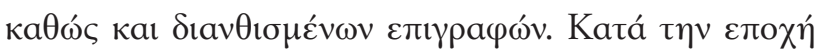

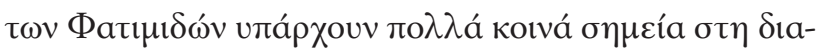

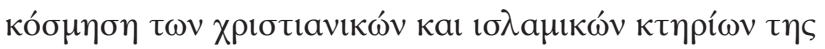

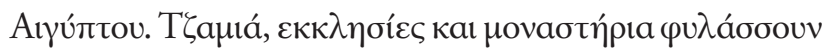

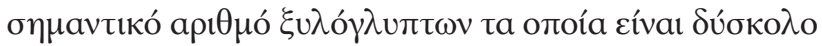

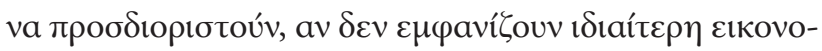

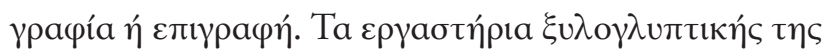

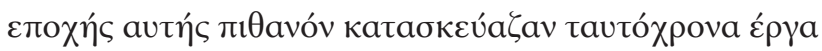

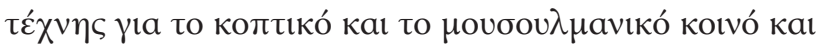

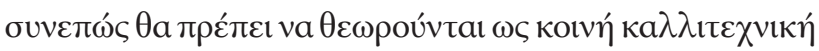

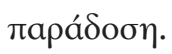

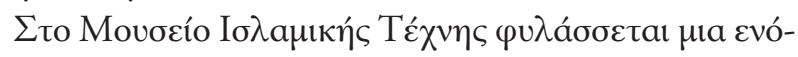

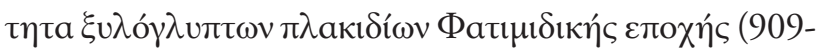

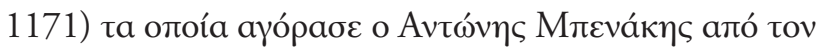

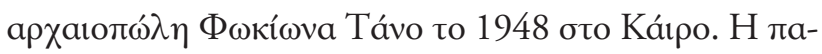

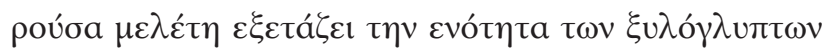

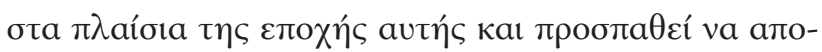




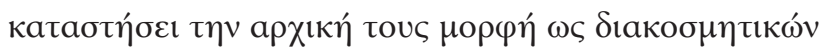

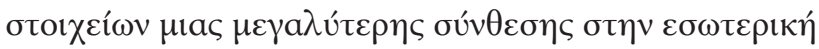

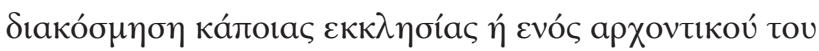

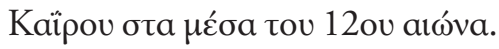

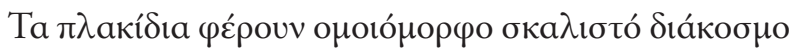

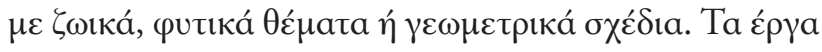

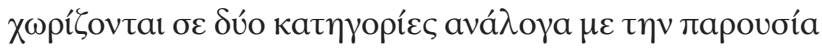

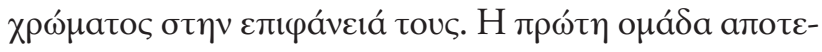

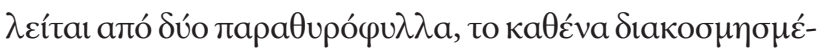

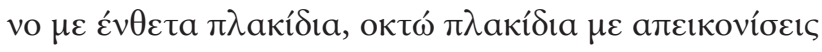

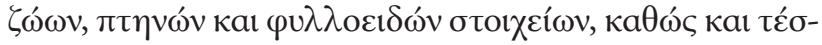

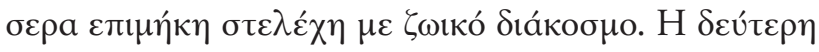

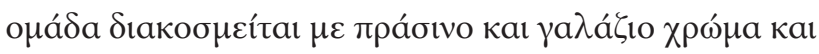

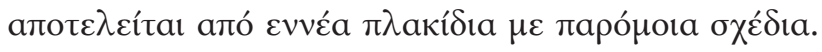

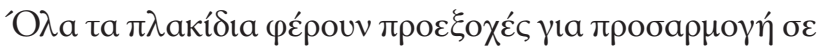
$\mu \varepsilon \gamma a \lambda u ́ \tau \varepsilon \rho \eta ~ \sigma u ́ v \theta \varepsilon \sigma \eta$.

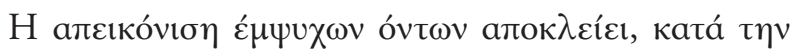

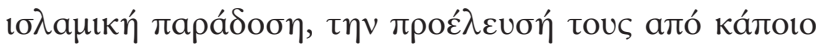

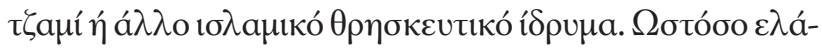

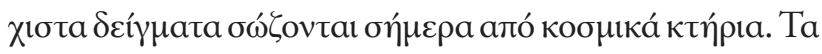

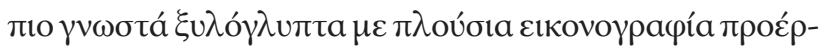

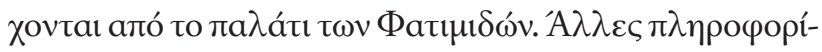

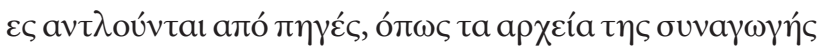

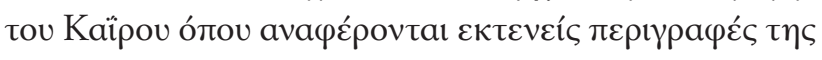

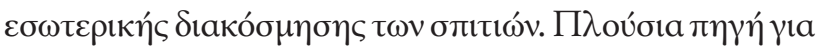

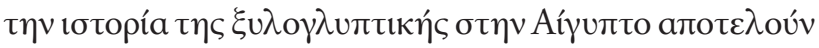

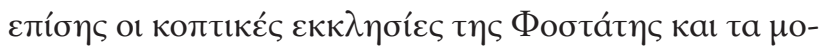

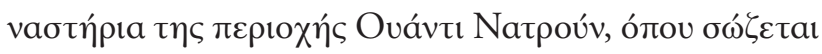

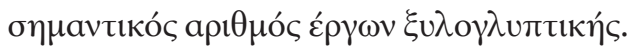

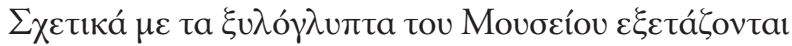

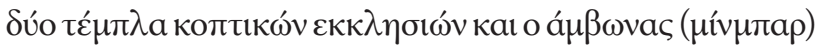

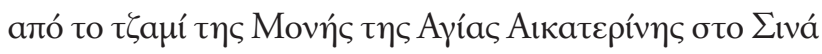

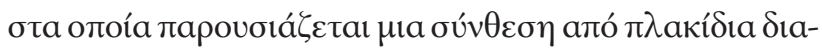

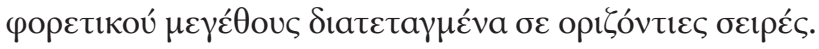

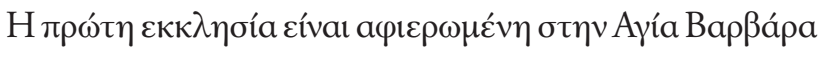

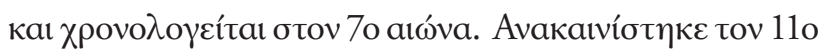

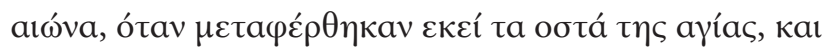

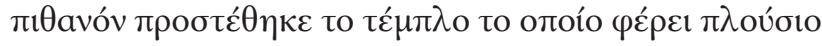

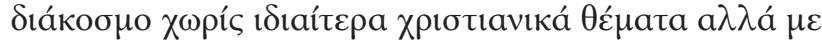

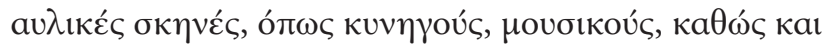

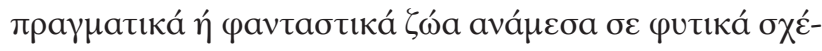

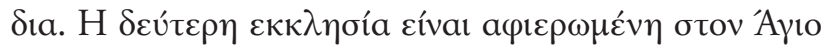

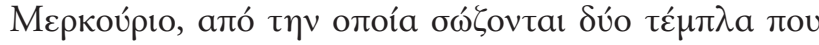

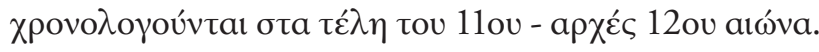

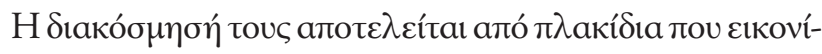

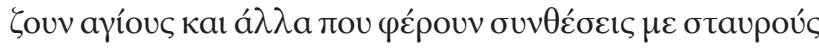

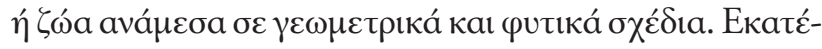

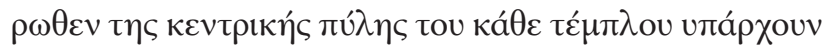

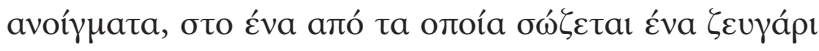

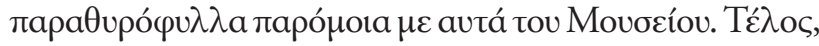

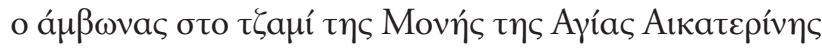

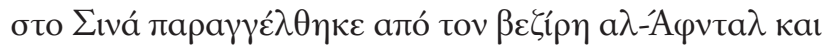

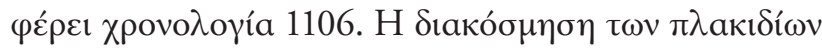

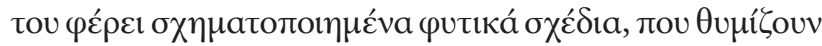

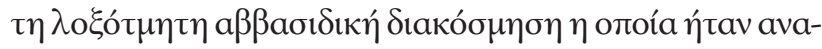

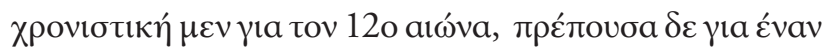

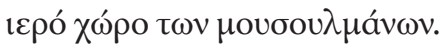

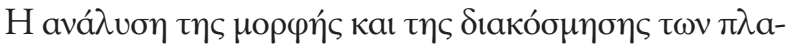

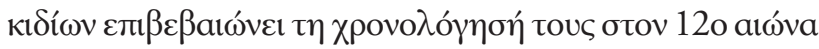

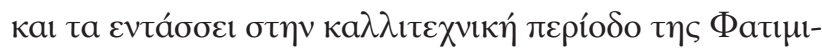

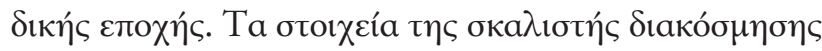

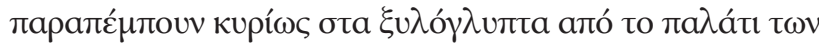

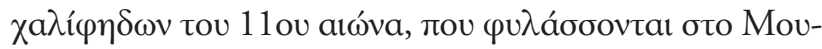

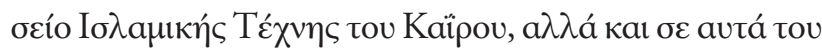

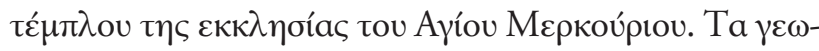

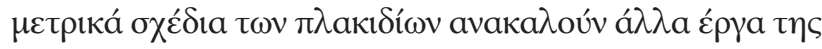

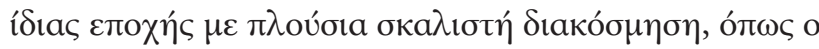

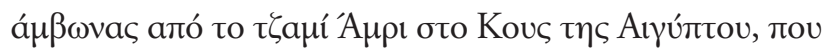

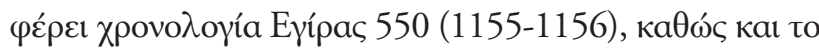

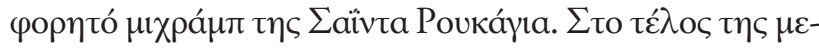

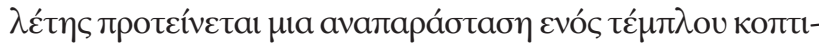

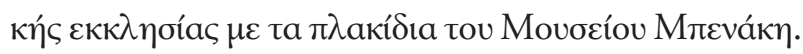

